\title{
PENGGUNAAN MEDIA WORDWALL SAAT PANDEMI COVID-19 PADA MATA PELAJARAN SENI BUDAYA DI SMP
}

\author{
Ida Nisaurrasyidah $^{1^{*}}$, Z. S. Soeteja ${ }^{2^{*}}$, Nanang G. Prawira ${ }^{3 *}$ \\ Program Studi Pendidikan Seni Sekolah Pascasarjana \\ Universitas Pendidikan Indonesia \\ Jl. Dr. Setiabudi, No. 229, Isola, Kec. Sukasari, Kota Bandung, Kode Pos 40154 \\ Jawa Barat. Indonesia \\ Email: senoridaziggy@gmail.com,zakarias@upi.edu,nananggandaprawira26@upi.edu
}

\begin{abstract}
Abstrak
Sudah lebih dari satu tahun lamanya negara kita terkena pandemi virus Covid-19. Hal ini berimbas pada semua sektor, termasuk sektor pendidikan. Kegiatan pembelajaran terutama pada daerah yang masih berada di zona merah harus dilakukan secara online. Pada saat ini banyak guru yang menyampaikan materi dengan menggunakan video pembelajaran melalui Youtube lalu memberi tugas kepada siswa. Termasuk guru mata pelajaran Seni Budaya. Metode belajar ini membuat siswa merasa jenuh dan menjadi kurang disiplin. Guru diharapkan untuk lebih kreatif dan inovatif dalam kegiatan pembelajaran. Salah satunya dengan menggunakan media pembelajaran Wordwall. Hal ini menjadi alasan peneliti untuk meneliti tentang Penggunaan Media Game Pembelajaran Wordwall pada Mata Pelajaran Seni Budaya. Media game pembelajaran ini berbasis website selain mudah digunakan namun juga menyenangkan bagi siswa. Selain itu beberapa dari jenis permainan dari media game pembelajaran Wordwall dapat dicetak menggunakan printer dan dapat dikerjakan langsung oleh siswa. Jadi Media game Wordwall dapat membantu guru dalam kegiatan pembelajaran yang menyenangkan bagi siswa sehingga tujuan pembelajaran dapat tercapai secara optimal.
\end{abstract}

Kata Kunci: media pembelajaran online, wordwall.

\begin{abstract}
It has been more than a year since our country has been hit by the pandemic COVID-19. This affects all sectors, including the education sector. Learning activities, especially in areas that are still in the red zone, must be carried out online. At this time many teachers deliver material using learning videos via Youtube and then give assignments to students. Including a teacher of Cultural Arts subjects. This learning method makes students feel bored and less disciplined. Teachers are expected to be more creative and innovative in learning activities. One of them is by using Wordwall learning media. This is the reason for researchers to examine the use of Wordwall Learning Game Media in Cultural Arts Subjects. This website-based learning game media is not only easy to use but also fun for students. In addition, several types of games from the Wordwall learning game media can be printed using a printer and can be done directly by students. So Wordwall game media can help teachers in fun learning activities for students so that learning objectives can be achieved optimally.
\end{abstract}

Keywords: online learning media, wordwall.

\section{PENDAHULUAN}

Sudah lebih dari setahun lamanya kemunculan infeksi virus Covid-19. Virus ini sudah memakan banyak korban jiwa. sehingga WHO (World Health Organization) menyatakan wabah ini sebagai Pandemi Global. Akibat kemunculan dari virus ini, semua sektor terkena imbasnya, termasuk pada sektor pendidikan. Virus ini menyerang segala usia, baik tua maupun muda. Yang lebih beresiko adalah orang dengan usia lanjut dan juga anak-anak.

Dalam menyikapi kondisi pandemi Covid-19 saat ini maka pembelajaran di tahun ajaran baru 2021/2022 bersifat dinamis mengacu pada kebijakan
Pemberlakuan Pembatasan Kegiatan Masyarakat (PPKM) di masing-masing daerah, dan Keputusan Bersama (SKB) 4 Menteri tentang Panduan Penyelenggaraan Pembelajaran di Masa Pandemi Covid-19. Beberapa daerah sudah ada yang tatap muka, namun beberpa daerah masih berada di zona merah dan harus mewajibkan pembelajaran jarak jauh.

Pendidikan dan Kebudayaan Republik Indonesia mengeluarkan Surat Edaran Nomor 4 Tahun 2020 Tentang Pelaksanaan Kebijakan Pendidikan Dalam Masa Darurat Penyebaran Corona virus Disease (Covid-19) poin ke 2 yaitu proses belajar dari rumah dilaksanakan dengan ketentuan sebagai berikut: (1) 
belajar dari rumah melalui pembelajaran daring/jarak jauh dilaksanakan untuk memberikan pengalaman belajar yang bermakna bagi siswa, tanpa terbebani tuntutan menuntaskan seluruh capaian kurikulum untuk kenaikan kelas maupun kelulusan; (2) belajar dari rumah dapat difokuskan pada pendidikan kecakapan hidup antara lain mengenai pandemic Covid-19; (3) aktivitas dan tugas pembeljaran belajar dari rumah dapat bervariasi antarsiswa, sesuai minat dan kondisi masing-masng, termasuk mempertimbangkan kesenjangan akses/ fasilitas belajar dirumah; (4) bukti atau prosuk aktivitas belajar dari rumah diberi umpan balik yang bersifat kualitatif fan berguna dari guru, tanpa diharuskan memberi skor/nilai kuantitatif (Kemendikbud, 2020).

\section{KAJIAN TEORI}

Perbedaan perbedaan pembelajaran secara tatap muka dan pembelajaran online. Ciri dari pembelajaran online atau daring adalah integrasi teknologi dan inovasi yang ada didalamnya (Banggur, Situmorang, \& Rusmono, 2018) Kegiatan pembelajaran jarak jauh pada daerah yang masih berada di zona merah, dapat dilakukan secara online menggunakan aplikasi virtual yang dapat terhubung dengan sambungan internet.

Pada mata pelajaran Seni Budaya terdapat 2 Kompetensi Dasar (KD) yaitu tentang memahami pengetahuan seni dan membuat karya seni. Sebelum membuat karya seni, maka siswa perlu Mata pelajaran Seni Budaya kerap kali dipandang sebelah mata. Padalah baik disadari atau tidak, kita semua membutuhkan seni. Dengan mata pelajaran Seni Budaya, siswa menjadi tahu nilai-nilai budaya bangsa dan memperoleh pengalaman berkesenian. Mata pelajaran ini juga menyeimbangkan antara otak kanan dan otak kiri dengan menumbuhkan kreativitas siswa secara lebih terarah.

Sudah lebih dari setahun lamanya kegiatan pembelajaran secara online dilakukan. Selama setahun ini para guru berusaha untuk kreatif dan berinovasi dalam kegiatan pembelajaran agar anak tidak jenuh belajar dan tujuan pembelajaran dapat tersampaikan. Saat ini kegiatan pembelajaran dilakukan diantaranya dengan mengirimkan video pembelajaran untuk dilihat oleh siswa, lalu guru memberi tugas melalui Google Form. Banyak guru berlomba-lomba membuat video pembelajaran yang menarik. Biasanya guru membuat video pembelajaran dengan mengeditnya terlebih dahulu lalu mengunggahnya ke Youtube. Selanjutnya guru mengirimkan alamat linknya melalui WhatsApp atau Google Classroom kepada siswa.
Namun pada kenyataannya ketika siswa diminta untuk melihat video pembelajaran dan diberi tugas oleh guru, hanya sedikit siswa yang mengerjakan tugas tersebut. Penggunaan metode yang sama membuat siswa jenuh serta kurang bersemangat dalam kegiatan pembelajaran. Tidak hanya itu, video pembelajaran dapat dilihat kapanpun dan dimanapun, hal ini membuat siswa menjadi tidak disiplin yang mengakibatkan nilai pengetahuannya menurun sehingga tujuan pembelajaran tidak tercapai.

Maya dari itu guru dituntut untuk kreatif dan inovatif agar tujuan pembelajaran dapat tersampaikan. Greenhow dan Robelia berpendapat, "Pembelajaran yang tepat diterapkan dalam kurikulum 2013 yaitu menekankan pada learning by doing sebagai upaya untuk melatih kompetensi siswa. Kompetensi tersebut diharapkan dapat meningkatkan pemecahan masalah dan berfikir kritis siswa proses pembelajaran." (Permansah \& Murwaningsih, 2018).

Pada era industri 4.0 para remaja saat ini tengah digandrungi dengan penggunaan gadget yang diisi berbagai aplikasi. Salah satunya adalah game online. Game online kerap kali dinilai negatif. Padahal game dapat juga bernilai positif jika digunakan dengan tepat.

Cheung dalam Permasah dan Murwaningsih mengatakan, "Penggunaan media pembelajaran yang dimaksud selain bertujuan untuk mempermudah dalam penyampaian materi dari guru ke siswa juga dapat meningkatkan minat serta kemauan siswa pada mata pelajaran tertentu." (Permansah \& Murwaningsih, 2018). Sudah banyak penelitian yang telah dilakukan dalam rangka pengembangan media pembelajaran dengan memanfaatkan perkembangan teknologi digital. Namun belum ada penelitian yang berfokus pada kajian media game wordwall dan dikhususkan pada mata pelajaran Seni Budaya.

\section{METODE PENELITIAN}

Pendekatan dalam penelitian ini menggunakan jenis penelitian studi literatur atau studi kepustakaan. Mardais dalam Rizal dan Dani mengatakan, "Studi literatur dapat ditempuh dengan jalan mengumpulkan referensi yang terdiri beberapa penelitian terdahulu yang kemudian dikompilasi untuk menarik kesimpulan” (Hartanto \& Dani, 2020). Langkahlangkah penelitian ini dilaksanakan sebagai berikut: (1) pilih tema; (2) eksplorasi informasi; (3) penentuan arah penelitian; (4) mengumpulkan sumber data; (5) penyajian data; (6) menyusun laporan. 
Teknik analisisnya dilakukan menggunakan metode analisis isi. Dalam analisisnya akan dilakukan pemilihan, pembandingan, penggabungan, dan pemilahan sehingga ditemukan yang relevan. (Sabarguna, 2005). Pengecekan antar pustaka dan pemerhatian terhadap komentar pembimbing dilakukan guna menjaga kekekalan proses mengevaluasi, mencegah dan menghilangkan informasi yang salah merupakan kesalahpahaman manusia yang mungkin timbul karena kurangnya penulis pustaka. (Sutanto, 2005).

\section{HASIL DAN PEMBAHASAN}

\section{Hasil}

Media pada hakekatnya merupakan salah satu komponen sistem pembelajaran. Pemilihan media dalam kegiatan pembelajaran diharapkan akan ada interaksi antara guru dan siswa serta media pembelajaran yang kita pilih. Pemilihan media yang akan guru gunakan harus sesuai dengan kebutuhan dan kondisi sasaran didik. Media yang digunakan apakah sudah tersedia di sekolah, apakah media yang digunakan sesuai dengan tujuan pembelajaran yang guru rencanakan, dan apakah media pembelajaran yang kita gunakan terjangkau harganya.

Media pembelajaran adalah alat-alat bantu yang digunakan untuk menunjang pelaksanaan proses belajar mengajar, mulai dari buku sampai penggunaan perangkat elektronik di kelas. Fungsi media pembelajaran yaitu membantu menjelaskan atau memvisualisasikan suatu materi yang sulit dipahami. Beberapa fungsi media pembelajaran adalah : (1) pemusat perhatian siswa; (2) menggugah emosi siswa; (3) materi pembelajaran mudah dipahami; (4) membantu siswa menerima informasi; (5) menambah semangat dan motivasi siswa; (6) pembelajaran terasa lebih nyata; (7) memiliki banyak fungsi; (8) mengaktifkan pembelajaran; (9) menambah keberagaman metode dan strategi mengajar; (10) menambah keaktifan siswa.

Dalam menentukan media pembelajaran yang baik, Ambiyar dalam Handayani berpendapat bahwa sebaiknya guru mempertimbangkan hal berikut ini; (1) bersifat ekonomis, dalam pengertian bila dikurskan dengan uang, maka tergolong relative murah; (2) bersifat praktis dan sederhana, tidak memerlukan pelayanan khusus atau keterampilan khusus dalam mengoperasikan; (3) mudah diperoleh, dalam arti media tersebut mudah diperoleh di daerah sekitar,tidak perlu memesan khusus diperusahaan tertentu; (4) bersifat fleksibel, artinya dapat dimanfaatkan untuk berbagai tujuan instruksional dan tidak dan tidak dipengaruhi oleh faktor luar; (5) komponenkomponennya sesuai dengan tujuan, artinya misi,keadaan fisik,dan pesan yang dibawa oleh media harus sesuai dengan tujuan (Handayani, 2014).

Salah satu aplikasi yang dapat digunakan untuk membuat media pembelajaran yang interaktif adalah Wordwall. Aplikasi berbasis website ini dapat digunakan untuk membuat media pembelajaran seperti kuis, menjodohkan, memasangkan pasangan, anagram, acak kata, pencarian kata, mengelompokkan, dlsb. Menariknya lagi, selain pengguna dapat menyediakan akses media yang telah dibuatnya melalui daring, juga dapat diunduh dan dicetak pada kertas. Aplikasi ini menyediakan banyak template yang dapat diakses secara gratis serta pengguna dapat berganti template aktivitas satu ke aktivitas lainnya dengan mudah.

Langkah-langkah membuat media game pembelajaran Wordwall yaitu: (1) mendaftarkan akun di https://wordwall.net/ ; (2) klik "Sign Up" lalu isikan nama, alamat email, kata sandi dan lokasi akun; (3) pilih "Create Activity" lalu pilih salah satu template aktivitas yang disediakan; (4) tuliskan judul dan deskripsi permainan; (5) ketikkan konten yang ingin dipilih sesuai dengan tipe permainannya, pada beberapa jenis permainan dapat diperkenankan mengunggah gambar; (6) klik "Done" jika telah selesai.

\section{Pembahasan}

Pendidikan seni dan budaya sangat penting dikembangkan. Pada dasarnya, konsep pendidikan seni ada dua macam, yang pertama yaitu konsep pendidikan seni yang berkaitan dengan aspek ekspresi artistic dan kedua yaitu konsep pendidikan seni yang dikaitkan dengan tujuan pendidikan. Dalam mata pelajaran Seni Budaya dan Keterampilan, aspek budaya tidak dibahas secara tersendiri tetapi terintegrasi dengan seni. Karena itu mata pelajaran Seni Budaya dan Keterampilan pada dasarnya merupakan pendidikan seni yang berbasis budaya. (Widianingsih, 2012).

Sekolah memberikan mata pelajaran Seni Budaya sebab memiliki kebermaknaan, keunikan, dan kebermanfaatan untuk memenuhi kebutuhan peserta didik. Dengan memberikan pengalaman keindahan atau estetik dan juga berekspresi /berkreasi melalui kegiatan berkesenian melalui: "belajar dengan seni" atau "belajar melalui seni" dan "belajar tentang seni.". Karena itu Seni Budaya mampu menyeimbangkan kebutuhan otak kanan dan kiri peserta didik. Peran ini tidak dapat diberikan oleh mata pelajaran lain. 
Mata pelajaran Seni Budaya memiliki 2 Kompetensi Dasar, yaitu memahami pengetahuan seni dan membuat karya seni. Sebelum membuat karya seni, siswa diberi pengetahuan mengenai karya seni yang ingin dibuatkan. Media pembelajaran memudahkan guru dalam menyampaikan materi tersebut.

Dalam pelajaran Seni Budaya di SMP pada kelas 7 semester 1, materi yang diajarkan ada dua jenis didalamnya ada Menggambar Florra, Fauna dan Alam Benda lalu Menggambar Ragam Hias. Pada semester 2 materi yang diajarkan yaitu Menggambar Ragam Hias pada Bahan Tekstil dan Menggambar Ragam Hias pada Bahan Buatan. Jenis Game Wordwall yang digunakan ada banyak. Salah satunya yaitu Whack a Mole. Berikut ini contoh gambar implementasi media game Wordwall di mata pelajaran Seni Budaya bidang (Seni Rupa) kelas 7 dengan materinya yaitu Menggambar Flora, Fauna dan Alam Benda:

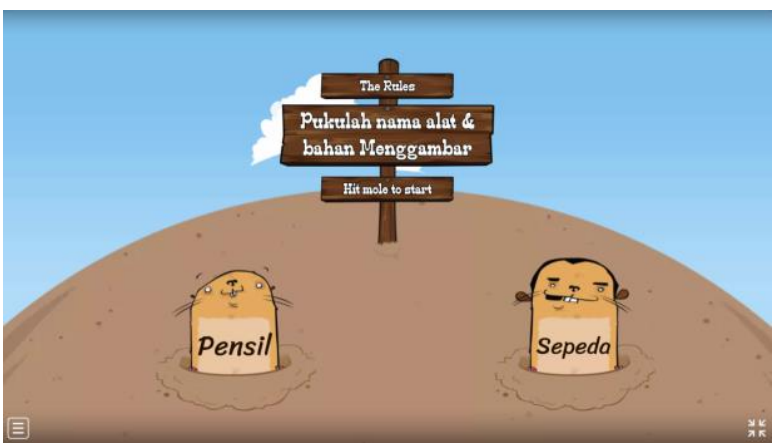

Gambar 1. Game Wordwall pada Mata Pelajaran Seni Budaya Materi Menggambar Flora, Fauna dan Alam Benda Kelas 8 (IdaSeniRupa, 2021)

Jenis game Whack a Mole meminta pemain untuk memukul tikus yang bertuliskan alat dan bahan dalam Menggambar. Guru dapat mengedit materi yang disampaikan kepada siswa kelas 7. Selain itu guru dapat mengatur lamanya waktu bermain dan level permainan. Jika sudah guru dapat mengatur peringkat score tertinggi. Lalu mengirimkan alamat link game Wordwall pada siswa untuk dimainkan saat pembelajaran.

Dalam pelajaran Seni Budaya di SMP pada kelas 8 semester 1, materi yang diajarkan yaitu Menggambar Model dan Menggambar Ilustrasi. Sedangkan materi yang diajarkan pada semester 2 yaitu Menggambar Poster dan Menggambar Komik. Ada banyak jenis game Wordwall yang dapat dibuat konten sebagai medi pembelajaran. Berikut ini contoh gambar implementasi media game Wordwall jenis Airplane di mata pelajaran Seni Budaya bidang Seni Rupa dengan materinya yaitu Menggambar Poster pada kelas 8.

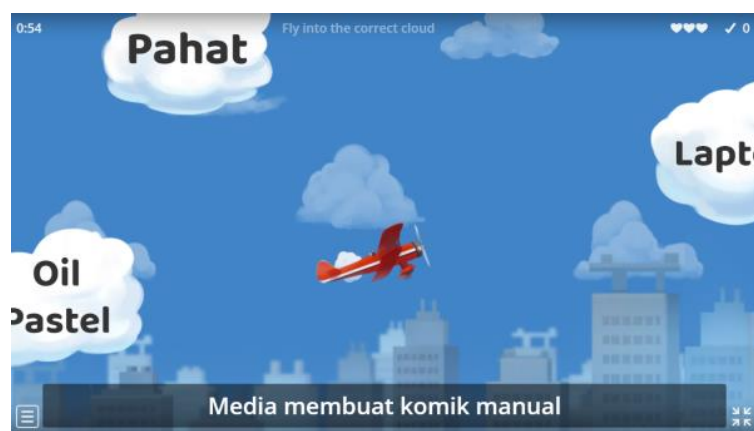

Gambar 2. Game Wordwall pada Mata Pelajaran Seni Budaya Materi Menggambar Komik Kelas 8 (SenoridaZiggy, 2021)

Jenis game Airplane meminta pemain untuk mengarahkan pesawat menuju awan yang bertuliskan jawaban yang tepat. Guru dapat mengedit materi yang disampaikan kepada siswa kelas 8 . Selain itu guru dapat mengatur lamanya waktu bermain dan level permainan. Jika sudah guru dapat mengatur peringkat score tertinggi. Lalu mengirimkan alamat link game Wordwall pada siswa untuk dimainkan saat pembelajaran.

Dalam pelajaran Seni Budaya di SMP pada kelas 9 semester 1, materi yang diajarkan yaitu Seni Lukis dan Seni Patung. Sedangkan materi yang diajarkan pada semester 2 yaitu Seni Grafis dan Penyelenggaraan Pameran. Ada banyak jenis game Wordwall yang dapat dibuat konten sebagai media pembelajaran. Berikut ini contoh gambar implementasi media game Wordwall jenis Match Up pada materi Menggambar Poster mata pelajaran Seni Budaya (Seni Rupa) Kelas 9:

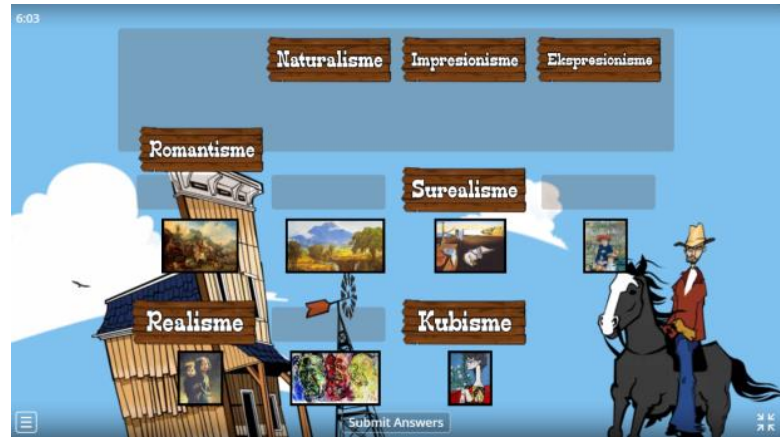

Gambar 3. Game Wordwall pada Mata Pelajaran Seni Budaya Materi Seni Lukis Kelas 9

(Nugraha, 2021)

Jenis game Match $U p$ meminta pemain untuk menjodohkan aliran-aliran seni lukis dengan gambar lukisan. Guru dapat mengedit materi yang disampaikan kepada siswa kelas 9. Selain itu guru dapat mengatur lamanya waktu bermain dan level permainan. Jika sudah guru dapat mengatur peringkat score tertinggi. Lalu mengirimkan alamat link game Wordwall pada siswa untuk dimainkan saat pembelajaran. 


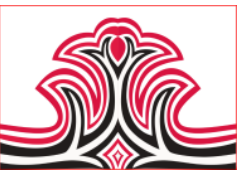

Anak akan lebih bersemangat dan merasa senang dalam memainkan game ini. Media pembelajaran wordwall mudah digunakan, praktis dan juga menyenangkan dalam mata pelajaran Seni Budaya sehingga anak menjadi semangat dan lebih mudah menerima materi yang guru berikan.

\section{KESIMPULAN DAN SARAN}

\section{Kesimpulan}

Pembelajaran Jarak Jauh (PJJ) selama pandemi memerlukan bantuan jaringan internet. Untuk memperbaharui strategi, metode dan media pembelajaran yang lebih baik serta menjadi seorang yang kreatif dan inovatif guru perlu mengikuti arus perkembangan zaman masa kini. Sehingga siap untuk mengelola kelas meskipun online. Meningkatkan minat, motivasi dan hasil belajar anak dalam mengikuti mata pelajaran Seni Budaya.

Pengalaman keindahan atau disebut juga dengan estetik diberikan dalam mata pelajaran Seni Budaya. Didalamnya dikenalkan, "belajar dengan seni" dan juga "belajar melalui seni". Mata pelajaran lain tidak memberikan pengalaman ini.

Pada mata pelajaran Seni Budaya terdapat 2 Kompetensi Dasar, yaitu memahami pengetahuan seni dan membuat karya seni. Sebelum membuat karya seni siswa diberi pengetahuan mengenai karya seni. Dalam memberikan materi Seni Budaya, guru dapat menggunakan media game online Wordwall selama pembelajaran. Media game ini mudah digunakan dan menyenangkan bagi siswa. Dapat disimpulkan bahwa penggunaan game Wordwall dapat menjadi media pembelajaran yang mudah digunakan, praktis, efektif dan menyenangkan pada mata pelajaran Seni Budaya bagi siswa.

\section{Saran}

Saran bagi guru agar lebih kreatif dan inovasi lagi dalam membuat media pembelajaran secara online terudala dalam menggunakan media game Wordwall. Saran bagi siswa, semoga dengan adanya media game ini lebih termotivasi lagi dalam mengikuti kegiatan pembelajaran Seni Budaya. Bagi peneliti lain semoga dapat mengembangkan lagi penelitian mengenai media pembelajaran online, terutama media game Wordwall khususnya pada mata pelajaran Seni Budaya.

\section{DAFTAR RUJUKAN}

Banggur, M. D., Situmorang, R., \& Rusmono, R. (2018). Pengembangan Pembelajaran Berbasis Blended Learning Pada Mata Pelajaran
Gorga : Jurnal Seni Rupa

Volume 10 Nomor 02 Juli-Desember 2021

p-ISSN: 2301-5942 | e-ISSN: 2580-2380

Etimologi Multimedia. Jurnal Teknologi Pendidikan. 20 (2) 152-165.

http://journal.unj.ac.id/unj/index.php/jtp/artic le/view/8629/5867

Handayani, N. (2014). Penggunaan Media Pembelajaran Untuk Peningkatan Prestasi Belajar. An-Nuha. 89(2) 81-97. http://ejournal.staimadiun.ac.id/index.php/an nuha/article/view/19

Hartanto, R. S., \& Dani, H. (2020). Studi Literatur: Pengembangan Media Pembelajaran Dengan Software Autocad. Jurnal Kajian Pendidikan Teknik Bangunan. 2 (2) 1-6.

https://ejournal.unesa.ac.id/index.php/jurnalkajian-ptb/article/view/35881

IdaSeniRupa. (2021). Seni Rupa Kelas 7. www.wordwall.net (diakses tanggal 8 Juni 2021).

Kemendikbud, P. W. (2020). Mendikbud Terbitkan SE tentang Pelaksanaan Pendidikan dalam Masa Darurat Covid-19. www.kemdikbud.go.id (diakses tanggal 24 Maret 2020).

Nugraha. (2021). Pasangkanlah Aliran dan Lukisan di bawah ini. www.wordwall.net (diakses tanggal 28 Juli 2021)

Permansah, S., \& Murwaningsih, T. (2018). Media Pembelajaran Digital: Kajian Literatur Tentang Dampak Penggunaan Media Pembelajaran Digital di SMK. Prosiding Seminar Nasional Pendidikan Administrasi Perkantoran (SNPAP). 74(2) 72-76.

Sabarguna, B. S. (2005). Analisis Data pada Penelitian Kualitatif. Jakarta: PT. Raja Grafindo Persada.

SenoridaZiggy. (2021). Arahkan Pesawat Menuju Awan yang Tepat. www.wordwall.net (diakses tanggal 9 April 2021).

Sutanto, L. (2005). Teori Konseling dan Psikoterapi Perdamaian. Malang: UNM.

Widianingsih, E. (2012). Pembelajaran Seni Budaya dan Keterampilan Menumbuhkan Kecerdasan Moral Secara Kompetitif. Edu Humaniora. 5 (2)1-6. https://ejournal.upi.edu/index.php/eduhumani ora/article/view/2826/1847 